\title{
FROM CRIMINALISTICS TO CSI: WARSAW. PRACTICAL METHODS OF TEACHING CRIMINALISTICS AT THE DEPARTMENT OF CRIMINALISTICS, UNIVERSITY OF WARSAW ${ }^{1}$
}

\begin{abstract}
Hallo, hallo! Police? I don't know what has happened... My husband is laying covered in blood and is not breathing... Please help me! ${ }^{2}$
\end{abstract}

\section{CSI EFFECT. POPULARIZATION OF FORENSIC SCIENCE}

Work of forensic personnel at the scene of crime got popularized by TV series, such as CSI: Crime Scene Investigation and its spin offs that started airing at the end of the $20^{\text {th }} /$ beginning of the $21^{\text {st }}$ century. For more than a decade CSI franchise was the most popular TV series worldwide ${ }^{3}$ that prepared audience for more specific series, such as Dexter, Bones and alike. Until than all the credits for solving criminal cases got detectives investigating them. The vision of lonely genius solving the most difficult riddles has been awakening the imagination of general audience since the early $19^{\text {th }}$ century novels of Edgar Alan Poe, than sir Arthur Conan Doyle and later Agatha Christie to mention just those who have laid the foundation of the crime novel genre. Detectives created by them (often civilians) were using mostly their brains and logical thinking to solve cases labelled unbreakably by the

${ }^{1}$ I would like to thank to all people that helped me develop my skills in teaching. Firstly, all the students that I have met during last 12 years. Than, people with whom I worked. I can not mention everybody therefore will just express my gratitude to Magdalena Tomaszewska-Michalak with whom I have only good experiences in developing and teaching several different classes. Thank you Magda!

${ }^{2}$ CSI: Warsaw 911 call transcript.

${ }^{3}$ N. Andreeva, "CSI" Lives On, Wins Most Watched Drama Series Award At Monte Carlo TV Festival, Deadline. June 16, 2016, http://deadline.com/2016/06/csi-big-bang-theory-better-callsaul-monte-carlo-tv-festival-awards-1201774233/ (visited: November 20, 2017). 
police. Those so called "armchair detectives" forged the imagination of the police and investigative work for more than next 100 years and still attracts imagination of many people ${ }^{5}$. Even TV series that were produced through $20^{\text {th }}$ century were copying the scheme of the brilliant one or few police officers, private detectives or civilians that working on their own often against the corrupted or incompetent environment were cracking the case. No matter if it was homicide, sexual assault or organized crime. Major change took place when CSI franchise (after success of CSI: Las Vegas producers introduced spin-offs CSI: Miami, CSI: New York and CSI: Cyber) got introduced in 2000. Hi-tech - some times Star Trek alike - equipment used by detectives-scientists fit in the expectations of fair, just and unbiased law enforcement personnel contrasting the shady and corrupt operations of both real life and cops. Global popularity of CSI dramas resulted in so-called CSI effect ${ }^{6}$. That is actually a group of different influences that exaggerated the picture of forensic science. One of the expected effects is that jurors who watch such series expect more scientific evidence, especially DNA during trials ${ }^{7}$. Several studies found that CSI viewers generally have higher expectations than non-CSI viewers but the CSI viewers have higher expectations about scientific evidence that is more likely to be relevant ${ }^{8}$. One of the CSI "side effects" is the interest in the forensic science as an occupation, establishing several academic institutions and education programs not only in US ${ }^{9}$ and $\mathrm{UK}^{10}$ but also in continental Europe ${ }^{11}$, including Poland ${ }^{12}$. "Fruits" of that interest in forensic science will be later discussed in this paper.

${ }^{4}$ M. R. Sullivan, Armchair Detective, (in:) R. Herbert, C. Aird, J. M. Reilly, S. Oleksiw (eds.), The Oxford Companion to Crime and Mystery Writing, Oxford University Press 1999.

${ }^{5}$ P. Karasek, P. Waszkiewicz, Fotelowi detektywi w XXI wieku. Sposoby angażowania społeczeństwa do rozwiązywania spraw kryminalnych oraz korzyści i zagrożenia z tego plynace [Armchair Detectives in the 21st Century. How the Public Can Help Solve Criminal Cases: The Benefits and Dangers], "Archiwum Kryminologii" 2015, Vol. 36.

${ }^{6}$ K. R. Roane, D. Morrison, The CSI Effect: On TV, it's all slam-dunk evidence and quick convictions. Now juries expect the same thing-and that's a big problem, U.S. News \& World Report, April 25, 2005.

${ }^{7}$ N. J. Schweitzer, M. J. Saks, The CSI effect: popular fiction about forensic science affects the public's expectations about real forensic science, "Jurimetrics" 2007, Vol. 47, No. 3, pp. 357-364.

${ }^{8}$ D. E. Shelton, The "CSI Effect": Does it Really Exist?, March 17, 2008, "National Institute of Justice Journal" 2008, Vol. 259, https://ssrn.com/abstract=1163231 (visited: November 20, 2017)

9 A. Lemaine, "CSI" spurs campus forensics scene, U-T San Diego, September 13, 2004, http://legacy.sandiegouniontribune.com/uniontrib/20040913/news_1c13csi.html (visited: November 20, 2017).

${ }^{10}$ T. Dowling, The grisly truth about CSI degrees, The Guardian, October 15, 2009, https:// www.theguardian.com/education/2009/oct/15/csi-effect-forensic-science (visited: November 20, 2017).

${ }^{11}$ S. Keuneke, H. Graß, S. Ritz-Timme, "CSI-Effekt" in der deutschen Rechtsmedizin Einflüsse des Fernsehens auf die berufliche Orientierung Jugendlicher, "Rechtsmedizin" 2010, Vol. 20, issue 5, p. 400, DOI:10.1007/s00194-010-0668-2.

${ }^{12}$ Katedra Kryminalistyki, http://kryminalistyka.wpia.uw.edu.pl/dydaktyka/ (visited: November 20, 2017). 


\section{FORENSIC SCIENCE < CRIMINALISTICS}

Formal definitions of forensic science vary, depending on country and author. The most popular may be describing it as "the application of scientific principles and techniques to matters of criminal justice especially as relating to the collection, examination, and analysis of physical evidence"13 and the other refers directly to the popularization by TV and its shortened form - forensics: "a fairly new, all-encompassing term, it characterizes the scientific examination of evidence. Owing to television and motion picture shows, the term is now generic and part of the vocabulary of the average person (and, therefore, jurors)"'14. In Poland and several other countries, mainly from the middle and east Europe (Czech Republic, Cyprus, Georgia, Serbia) the more often used term is criminalistics (German: Kriminalistik, Polish: kryminalistyka). However the understanding of what criminalistics is, again, may be very different depending on who and where forms the definition. The author of one of the most popular textbooks Richard Saferstein - "Criminalistics. An Introduction to Forensic Science" very clearly uses those 2 terms interchangeably and understands criminalistics/forensic science as: "the application of science to the criminal and civil laws that are enforced by police agencies in a criminal justice system" 15 . It is than broader than the other definition of criminalistics which limits it to the only a part of forensic science: "the branch of forensic science concerned with the scientific examination and interpretation of the minute details of physical evidence for the purpose of aiding the criminal investigator or a judge and jury during trail"16. Definitions of criminalistics (kryminalistyka) in Polish literature are much broader than those just quoted. According to them it is "practical field of science that develops principles of efficient operation, the use of technical and laboratory research methods in order to preventing crime, detecting crime and establishing the facts which are relevant as en evidence in criminal trail" ${ }^{\prime 7}$. To some extent it resembles the crime science, term first used when The Jill Dando Institute of Crime Science was funded, that is still vaguely defined, however it is to "merge prevention and detection under a scientific umbrella" ${ }^{18}$. Later in this paper by criminalistics I will

${ }^{13}$ Merriam-Webster, http://www.merriam-webster.com/medical/forensic\%20science (visited: November 20, 2017).

${ }^{14}$ J. W. Osterburg, R. H. Ward, Criminal Investigation. A Method for Reconstructing the Past, Anderson Publishing 2014, p. 624.

${ }^{15}$ R. Saferstein, Criminalistics. An Introduction to Forensic Science, Upper Saddle River, NJ: Pearson 2011, p. 4.

${ }^{16} \mathrm{~J}$. W. Osterburg, R. H. Ward, Criminal Investigation. A Method for Reconstructing the Past, Anderson Publishing 2014, p. 621.

${ }^{17}$ Z. Czeczot, T. Tomaszewski, Kryminalistyka ogólna, Toruń 1996, s. 16.

${ }^{18}$ G. Laycock, Defining Crime Science, (in:) M. Smith, N. Tilley (eds.), Crime science: new approaches to preventing and detecting crime, Cullompton 2005, p. 3. 
understand the field of science that applies methods and tools from every field of science in order to prevent, detect and gather the evidence relevant for the fair trail, so combining classical forensics with investigative and legal aspects that makes it very close to the quoted definition of Czeczot and Tomaszewski.

\section{CRIMINALISTICS AT POLISH UNIVERSITIES}

The emphasize on practical and legal aspects of criminalistics may explain why, since its emergence at the end of the $19^{\text {th }}$ century it is in the focus of law school students and professors. The future prosecutors, judges and advocates need to understand some principles of crime scene investigation in order to make their work the most efficient, especially baring in mind that: "For some reason, the forensic sciences have always had their fair share of charlatans"19.

In Poland criminalistics is taught at all law schools ${ }^{20}$ (both public and private) and at departments of internal security and criminology ${ }^{21}$. At some law schools it is one of mandatory courses (Katowice, Lublin) at others (including University of Warsaw) it is one of the elective courses. It means that student may choose between several different courses offered by the each law school in order to gather the required number of credits for passed courses. Courses on criminalistics offered at each university vary. At some the introductory course lasts 30 hours $\left(O s_{s t y n}{ }^{22}\right)$, others 45 hours $\left(\right.$ Lublin $\left.^{23}\right)$, up to 60 hours (Warszawa ${ }^{24}$ ). The duration of that basic course determines also the form in which it is taught - in most cases the course consists of lecture part (20-30 hours) and so-called exercises (ćwiczenia - practical part in smaller groups). At the University of Warsaw the introductory course into criminalistics is titled Criminalistics (Kryminalistyka ogólna)

${ }^{19}$ K. R. Roane, D. Morrison, The CSI Effect..., passim.

${ }^{20}$ Law schools in Poland are among a few other disciplines, like medicine, architecture, psychology that are not divided into two stages of study. All other students start with undergraduate 3 year program that finishes with licencjat equivalent to the bachelor degree and postgraduate, mostly 2 years finishing with master degree. Most of the law students start their studies directly after finishing high school (18/19 years old) and taking A-level exam. They enter uniform 5 years long program. More about legal education in Poland, see: I. Kraśnicka, Polish Legal Education in the Light of the Recent Higher Education Reform, "Michigan State Law Review" 2012, Vol. 2012, issue 2.

${ }^{21}$ Since the main focus of this paper is on legal education only that topic will be explored further.

${ }^{22}$ See: http://wpia.uwm.edu.pl/ksztalcenie/programy-ksztalcenia (visited: November 20, 2017).

${ }^{23}$ See: http://download.prawo.umcs.lublin.pl/Download/Informator_ECTS2012.pdf (visited: November 20, 2017).

${ }^{24}$ See: https://usosweb.uw.edu.pl/kontroler.php?_action=actionx:katalog2/przedmioty/pokazPrzedmiot(prz_kod:2200-1CWPK21) (visited: November 20, 2017). 
and is offered to the students who finished $2^{\text {nd }}$ year of the law school, so they are, among others, after the exam from Criminal Law and since that course is offered during Summer term many of them are taking Criminal Procedure course.

The Department of Criminalistics at the University of Warsaw was established in 1946 and its first chair was Professor Paweł Horoszowski. At that time the methods of teaching were limited to lectures and seminars ${ }^{25}$. That was changing step by step and in $90 \mathrm{~s}$ of the $20^{\text {th }}$ century the formal settings of the Criminalistics course at the University of Warsaw were formed. Half of time (30 houres) was devoted to lectures and half to the exercises. I had a chance to take that course at the beginning of the $21^{\text {st }}$ century. The exercises were taught at that time by Monika Całkiewicz (Korneć) and covered several practical issues, such as: fingerprinting, handwriting examination, facial composites preparations, interrogations. Those were one of the very few practical courses offered at that time to the law school students. Professor Całkiewicz students in their evaluations were praising her course as the sole practical one, offered at that time by the School of $\mathrm{Law}^{26}$. The other very practical program, but with emphasize on contact with the client and focus on helping in real cases was Law Clinic. Nobody needs to be convinced that practical methods of teaching create WIN-WIN-WIN situation ${ }^{27}$. First "WIN" means learning valuable and practical content. Interactive form of education allows to actually learn to contrast it with the form of the even the most interesting lecture. That is not only the "common knowledge" that the former way is more efficient, but the evidence based across different disciplines ${ }^{28}$. Second "WIN" is the the authentic interest of students in the course. They do not need to be forced to participate in such a course ${ }^{29}$.Third "WIN" is the satisfaction for an instructor. Doing something that is not boring for students and doing it on purpose. Interactive way of teaching is still not the "golden standard" what probably

${ }^{25}$ T. Tomaszewski, P. Girdwoyń, Tradycja i przyszłość w nauczaniu kryminalistyki na Uniwersytecie Warszawskim, "Problemy Współczesnej Kryminalistyki” 2008, Vol. 12.

${ }^{26}$ M. Korneć, Nauka kryminalistyki w ocenie studentów, "Problemy Współczesnej Kryminalistyki” 2002, Vol. 5.

${ }^{27}$ J. Elkington, Towards the Sustainable Corporation: Win-Win-Win Business Strategies for Sustainable Development, "California Management Review" 1994., Vol. 36, issue 2, DOI: $10.2307 / 41165746$.

${ }^{28}$ Hake R. R., Interactive-engagement versus traditional methods: A six-thousand-student survey of mechanics test data for introductory physics courses, "American Journal of Physics" 1998, Vol. 66.

${ }^{29}$ Since 2006 wen I started teaching Criminalistics by myself I am evaluating the course using anonymous questionnaires distributed among students during the last class. It consists of several open-ended questions to allow me to to find out what actually students (course participants) found interesting and valuable, what are their suggestions, what I should address during following years. For seven consecutive years some of the classes were starting at $8 \mathrm{AM}$, time not popular among students. Many answers were indicating that the fact that they were so early on time through the semester at the elective course is self evident as how they evaluate the course. 
everyone who studied or is studying knows. Students at the internet forums share their experiences from the most boring classes ${ }^{30}$ :

"However the subject seems to be interesting, the lecture is extremely boring. I recommend this lecture only with a set: a laptop or a book and plugs (to prevent the lecture from distracting you) and you will be fine, but without that equipment do not go there, because you will die of boredom. I still have trauma. (...)

Classes with ... rely solely on repeating the content of his textbook, case studies that we sometimes discuss are also from that book. Personally, I have learned absolutely nothing, maybe except the ability to sleep with open eyes :)"31.

"The whole bench -5 students, fell asleep on ... lecture. He did not interrupt a lecture, did not react, nothing. At that particular lecture there were 8 people present and in the room there are only 4 benches. We were sitting with eyes closed like a meter away from him" 32 .

\section{TEACHING CRIMINALISTICS BEFORE CSI: WARSAW}

Unfortunately, the experience of falling asleep at the boring classes was also shared by myself. Fortunately, I had a chance to participate in the interactive, workshop alike courses at few different academic institutions, such as: Institute of Applied Social Sciences University of Warsaw, Konstanz Universitat (Germany) and those mentioned at the School of Law. That what I learned thanks to many dedicated professors and how I wanted to be taught formed the way of approaching teaching responsibilities. The goals identified were as follows:

1) to teach in the most interactive way in that I would like to be taught by myself,

2) listening to the expectations of students and addressing them,

3) learning how to teach,

4) trying to develop the most effective way of teaching,

5 ) being interested by myself in what I teach.

In 2006 I started to teach Criminalistics at the University of Warsaw. Building on the experience from the classes taught by Professor Całkiewicz I have prepared my own syllabus that consisted of detailed scenarios for every single class. I have also developed teaching aids such as: multimedia presentations, sce-

${ }^{30}$ Those are examples only from University of Warsaw, but it is, unfortunately, very easy to identify several examples from literally any university of the world.

${ }^{31}$ P. Waszkiewicz, (Inter)aktywne zajęcia na prawie? Nauczanie przedmiotów prawno-ekonomicznych, (in:) Czy wspótczesny uniwersytet potrzebuje nowoczesnej dydaktyki szkoły wyższej?, Warszawa 2011.

${ }^{32}$ Cogito. 2016, http://www.cogito.com.pl/forum/index.php?topic=13980.140;wap2 (visited: November 20, 2017). 
narios for different kind of exercising interviews and interrogations. The latter are recorded on video and analyzed with the group after the exercise. Some classes were actually quasi-experimental ones that put the students in shoes of eyewitnesses to help them to learn better what they are taught during lectures and what they may learn from reading assignments. Since criminalistics encompasses also traditional forensic science techniques important part of the course is securing evidence in the field. Such classes as on: ballistics, shoe impressions, blood pattern analysis are taking place outside the classroom - in the field or other places that may accommodate the students and all necessary equipment.

Learning objectives of the course were that at the completion of this course, students are expected to:

1) understand the principles and terminology of various sub-disciplines of Criminalistics;

2) understand the role, value and necessity of Criminalistics for the Law Enforcement and Criminal Justice;

3) be able to find, identify and secure the evidence on the crime scene; and

4) be able to evaluate the evidence and it's quality from the procedural perspective.

As it was mentioned before the course consists from two parallel parts - lecture by Professor Tadeusz Tomaszewski for all the students participating in it and exercises which are organized for maximum 20 students in one group. However it is elective at the University of Warsaw it is very popular course chosen every year by around 140 students. Passing that course requires attending the lecture and exercises, as well as writing own paper on the chosen topic related to criminalistics. Some of the students in order to learn something new prepare their own little experiments which in some cases develop into topics of their master thesis or become the beginning of future academic career. Topics range from ballistics, through fingerprinting, entomology, odorology, psychics, forensic psychology, documents examination, to blood pattern analysis (BPA). As interest in criminalistics was fueled by CSI series, the interest in BPA is largely due to the Dexter series. It is hard not to mention here Kacper Choromański, former major in chemistry who after attending the criminalistics and several other courses in this field changed his major to law and after graduation continues his academic career in $\mathrm{BPA}^{33}$. In his first project he was testing popular culture cliché of dissolving bodies in the acid. That was one of several other projects that due to their significance and sensitive nature were not publicized outside only the limited audience. Dexter and Breaking Bad are another examples of a kind of a "pipe line" between popular culture and university criminalistics - fueling interest in the field among students who want to learn "how it is in real life".

${ }^{33} \mathrm{~K}$. Choromański, Wstęp do analizy śladów krwawych. Zagadnienia terminologiczne, “Współczesne Problemy Kryminalistyki” 2013, Vol. 17. 
During following years (2006-present) the program was changing. I was introducing new topics and developing more efficient teaching techniques. It has been also enriched by working with graduate students at the Department of Criminalistics that first took my course in Criminalistics (Kacper Gradoń and Magdalena Tomaszewska-Michalak) and later were teaching it by themselves. Listening to the expectations of students is implemented by anonymous evaluations. Students at the end of the course are filling in the open-ended questionnaire. This allowed me to adjust the form and content to their expectations. In 2013 my classes were also subject to the external anonymous evaluation carried out by School of Law in cooperation with the student association. The average overall rating of the course was 6.0 (excellent rating in scale 1.0-6.0). Since the first course I have taught at the first class participants are also asked about their expectations for this course and what they want to learn. One class each time is reserved to address their ideas expressed at the first class that I had not anticipated before.

In June 2008 as a special thanks for the best students participating in the Criminalistics classes and kind of an experiment together with Kacper Gradoń who that year started teaching Criminalistics we prepared additional class outside the university. It took place in the abandoned lamp factory in Warsaw (Zakłady Wytwórcze Lamp Elektrycznych im. Róży Luksemburg ${ }^{34}$ ). We have staged a scene of crime - the body of a female victim with several blood traces around it, as well as different other traces, including shoe prints, fingerprints and the weapon that could be used to commit that particular crime. We also invited a couple of our friends that students had not known before to role-play the witnesses and possible suspects. The group had to organize itself, divide responsibilities, secure the crime scene, proceed it carefully, secure the evidence and at the end present the possible course of events. We observed it for the next several hours without influencing the proceedings of our students only taking care of their physical safety, since some parts of that factory where threatening it and making notes. That was something that has influenced our thinking about teaching criminalistics. Students were utilizing all the knowledge and skills they have gained during the semester. It was unlike during course when they could have repeat securing their own fingerprint in case they failed for the first or the second time. At the scene of crime they had only one chance and they had no idea if secured evidence was actually relevant for their case. They had to decide by themselves what kind of traces they are looking for at particular item or area. Regarding witnesses they were again in charge to organize their interviews and - in case of suspecting their involvement in that crime. Staging that crime outside the university campus also played significant role. Students were moved out of their "comfort zones" - known place and settings - into real life. Those reasons as well as the satisfaction of students that participated in that event made as thinking how to utilize it in the future.

\footnotetext{
${ }^{34}$ Buildings of this particular factory were demolished in 2011.
} 


\section{CSI: WARSAW}

The idea to address the expectations of our students to learn more criminalistics in the most possible practical way was discussed with Professor Tadeusz Tomaszewski, head of Department of Criminalistics. He was opened for such idea and supported the application to University of Warsaw Innovative Teaching Fund (Fundusz Innowacji Dydaktycznych Uniwersytetu Warszawskiego) ${ }^{35}$. The application was called Crime Scene Investigation. Fiction vs. Reality. Only later there was introduced informal short form - CSI: Warsaw. That was of course "tribute" to all CSI series ${ }^{36}$. Eventhough I was the project leader we prepared the application together with Kacper Gradoń. In December 2008 the project got funding for the first two "seasons" of CSI: Warsaw. First "season" started in February 2009.

The objectives of the proposed course were as follows:

1) expending the educational offer of the University of Warsaw with a unique interdisciplinary practical course in fields of criminalistics, law and natural sciences;

2) improving the education of students at the University of Warsaw through the introduction of innovative investigative and legal activities;

3) providing participants with the ability to work at the scene, and critical assessment of their own activities;

4) preparing students to work in the criminal justice system, and to increase their attractiveness on the labor market by improving practical skills.

After completing the course the students were expected to:

1) have a comprehensive and in-depth knowledge of forensics and detection work;

2) know the practical aspects of securing and analyzing crime scene;

3) be aware of the need for a multidisciplinary approach to the problem of the analysis of the scene;

4) know the state of art in science and technology to support the work of detection and detention.

Since the course is very practical one there were also foreseen some practical skills to learn, such as:

1) planing to carry out the crime scene investigation in a variety of terrain and weather settings, and also at different times of the day and night;

2) preparing the interview and interrogation (including the specific categories of witnesses, e.g. children, foreigners etc.);

3) securing various types of forensic traces at the scene;

${ }^{35}$ That is special fund which is designed to promote innovative teaching projects at the University of Warsaw. Every year there is a formal call for proposals that need to be pre-approved by the departments and later are evaluated. Only those that are ranked as the best get funding. See: http://bss.uw.edu.pl/fid-5/ (visited: November 20, 2017).

${ }^{36}$ Term CSI: Warsaw was used for the first time as the wordplay title of my paper at the Festive of Science, September 2008: P. Waszkiewicz, CSI: Warsaw. Criminalistics in TV series. 
4) on the basis of the information gathered creating possible course of events (wersje śledcze), and planing further steps of law enforcement efforts;

5) ability to present secured evidence and to demonstrate its relationship with the case, translating/transferring the results of investigative work on the formal indictment.

Course due to its' nature was designed for a selected group of maximum 20 students of the final years. Prerequisites was successful finishing the "basic" course in criminalistics. Since the number of students who participate in criminalistics is several time bigger than the capability to organize specialized CSI: Warsaw course the recruitment procedure was introduced. Students interested in CSI: Warsaw were to prepare and submit CV and motivation letter. That is the first filter of those who are really interested to participate in that time and work demanding class. From the very beginning of that course the number of candidates is higher than number of places. It is than not an overstatement that those who were accepted were "hand picked".

Semester is divided into four parts corresponding to four different events (crimes but not always) staged by the lecturers with the active participation of part of the students who are also divided into four groups. Every group is responsible to develop the legend for the purpose of staging one event - the remaining three constitute the Criminal Investigation Division/Department (CID). To make those event as realistic as possible different settings are prepared and people who are not known by students take active part in it.

Each of those four parts of the semester is composed of three phases: theoretical preparation, practical and realistic simulation, and comprehensive evaluation.

In the first phase, students gain in-depth knowledge on crime scene investigation, and got familiar with a wide range of forensic techniques used to detect and secure traces. Since lecturers are aware of the coming event we try to address in that phase the anticipated issues. During the next stage, the task of CID is to: answer the 911 call, arrive at the staged scene, secure it and adequately proceed. Students use the forensic equipment and techniques and adhere to the procedures for determining the rules for carrying out their investigation. Particular attention is devoted to the rules of procedure for securing the protection of evidence against destruction, loss and contamination. Chain of custody and formal documentations are the key elements at that stage. Students among others, learn what kind of procedures and algorithms are to be applied at the scene. Those in particular include: securing the scene, proper documentation (sketches, forensic photography and video), systematic exploration, disclosure, protection and describing the evidence. The responsibilities of the CID encompass also interviewing witnesses they may encounter at the scene or other places connected to it, as well as interrogating suspects. In the latter case CID is also responsible for formal charges against suspects. After the crime scene investigation is finished CIDs' work is not finished. It is to evaluate the gathered evidence and within 24 hours decide what 
is to be submitted to the CIDs' forensic lab. Lab - constituted of lecturers and group that was staging the event - has another 24 hours to deliver forensic reports. Than CID is to prepare the most comprehensive story - possible course of events with legal decisions regarding charges for chosen individuals.

The third stage is devoted to the presentation of CIDs' work results. After they finished the discussion of their work takes place. During those classes we use footage documenting the behavior of the students at a staged scene. The main focus is on critical analysis of the best practices and mistakes made when securing evidence. That is to emphasize that such situations in actual investigative work may result in the destruction of elements that are of key importance for the criminal process information.

The time spent indoors and outdoors during that class is more than 100 hours without time spent on staging the scene, as well as out of class working on evidence and lab work. After first three seasons I had a great luck to start working together with Magdalena Tomaszewska-Michalak, with whom we prepared ("directed") four next CSI: Warsaw "seasons". That was time period when we have introduced - one by one - several new ideas into the course. Among them was one "night" episode in every "season" to confront students with the necessity of working also during night. The other was formal lab with budgetary limits, to make students being more careful while submitting evidence for the purpose of evaluation. To limit any physical danger to participants we introduced formal procedure to conduct any actions involving third parties. All of them paid off. In the evaluations students were sharing their gratitude for what they could learn. It is much easier for them to understand both investigative and prosecutorial work. Many of them in the following "seasons" were helping to organize new "episodes" for the benefit of their participants. Some of them develop their own careers in criminal justice and law enforcement system.

CSI: Warsaw was first such university program proposed not only in Europe. The closest resemblance to our project were bearing so called Crime Scene Houses - facilities, mostly located at the police academies were crimes were staged for purpose of training police skills. We were not aware of any course that was to take place in the real settings and involve so many variables. CSI: Warsaw during its first se7en seasons covered wide range of crimes, as well as events at first resembling them - suicides, accidents. No event took place in the same location or involved the same participants.

\section{CONCLUSIONS}

The number of benefits for students and teachers that participate in active learning projects such as CSI: Warsaw seems to be obvious and to some extent 
has been discussed earlier. What is not that clear are the downsides - possible obstacles, costs, "side effects" and even threats that are to be taken into account. I will try to list the main ones based on my own experience:

1. Large amount of work. Classes CSI Warsaw theoretically lasting 60 hours, in practice last more than 120 hours including the days off. This applies to both lecturers and students who are involved in the preparations and participation in these classes may neglect other duties.

2. Many students are become accustomed to "traditional" teaching methods. Classic lecture, even if it is some times a thrilling show does not require the student activity. Interactive activities can not be spend while "watching movies on the laptop". Student from an audience (the lecture) becomes an actor.

3. The possible lack of understanding of those who prefer "classic" style. Indicated a lack of understanding can occur both on the side of teachers as well as students. In extreme cases, it may to lead to the abandonment of interactive methods and adopting the dominant style.

4. A large number of uncontrolled variables. Interactive classes, especially when they take place outdoors, are ongoing, to some degree, uncontrolled process. The introduction of classes with a high degree of an authenticity often results in authentic emotions that are not always expressed in a gentle way. One should be aware therefor of opting for such a model.

5. Last, but not least the distinction between having fun and teaching. In some cases that border may become blurred to the degree when neither teachers nor students remember the original objective of such course. Spending with students hundreds of hours in different, often demanding circumstances creates a bond, sympathy, some times real friendships. The emotions that result from working on staged crimes are very real. That however does not change the roles in which both parties are. Teachers are to create save environment for teaching students. The main goal is not to become their friend - it is nice and appealing though and some times takes place. Forgetting about it results in devoting to much attention to the "fun part" on the expense of the learning objectives.

\section{BIBLIOGRAFIA}

Andreeva N., "CSI" Lives On, Wins Most Watched Drama Series Award At Monte Carlo TV Festival, Deadline. June 16, 2016. Accessed November 20, 2017, http:// deadline.com/2016/06/csi-big-bang-theory-better-call-saul-monte-carlo-tv-festivalawards-1201774233/ (visited: November 20, 2017)

Choromański K., Wstęp do analizy śladów krwawych. Zagadnienia terminologiczne, "Problemy Współczesnej Kryminalistyki” 2013, Vol. 17

Cogito. 2016, http://www.cogito.com.pl/forum/index.php?topic=13980.140;wap2 (visited: November 20, 2017) 
Czeczot Z., Tomaszewski T., Kryminalistyka ogólna, Toruń 1996

Dowling T., The grisly truth about CSI degrees, The Guardian, October 15, 2009, https:// www.theguardian.com/education/2009/oct/15/csi-effect-forensic-science (visited: November 20, 2017)

Elkington J., Towards the Sustainable Corporation: Win-Win-Win Business Strategies for Sustainable Development, "California Management Review" 1994, Vol. 36, issue 2, DOI: $10.2307 / 41165746$

Hake R. R., Interactive-engagement versus traditional methods: A six-thousand-student survey of mechanics test data for introductory physics courses, "American Journal of Physics" 1998, Vol. 66

Karasek P., Waszkiewicz P., Fotelowi detektywi w XXI wieku. Sposoby angażowania społeczeństwa do rozwiązywania spraw kryminalnych oraz korzyści i zagrożenia $z$ tego ptynace [Armchair Detectives in the 21st Century. How the Public Can Help Solve Criminal Cases: The Benefits and Dangers], "Archiwum Kryminologii" 2015, Vol. 36

Katedra Kryminalistyki, http://kryminalistyka.wpia.uw.edu.pl/dydaktyka/ (visited: November 20, 2017)

Keuneke S., Graß H., Ritz-Timme S., "CSI-Effekt” in der deutschen Rechtsmedizin. Einflüsse des Fernsehens auf die berufliche Orientierung Jugendlicher, "Rechtsmedizin" 2010, Vol. 20, issue 5, DOI: 10.1007/s00194-010-0668-2

Korneć M., Nauka kryminalistyki w ocenie studentów, “Problemy Współczesnej Kryminalistyki" 2002, Vol. 5

Kraśnicka I., Polish Legal Education in the Light of the Recent Higher Education Reform, "Michigan State Law Review" 2012, Vol. 2012, issue 2

Laycock G., Defining Crime Science, (in:) M. Smith, N. Tilley (eds.), Crime science: new approaches to preventing and detecting crime, Cullompton 2005

Lemaine A., "CSI" spurs campus forensics scene, U-T San Diego, September 13, 2004, http://legacy.sandiegouniontribune.com/uniontrib/20040913/news_1c13csi.html (visited: November 20, 2017)

Merriam-Webster, http://www.merriam-webster.com/medical/forensic\% $\% 20$ science (visited: November 20, 2017)

Osterburg J. W., Ward R. H., Criminal Investigation. A Method for Reconstructing the Past, Anderson Publishing 2014

Roane K. R., Morrison D., The CSI Effect: On TV, it's all slam-dunk evidence and quick convictions. Now juries expect the same thing-and that's a big problem, U.S. News \& World Report, April 25, 2005

Saferstein R., Criminalistics. An Introduction to Forensic Science, Upper Saddle River, NJ: Pearson 2011

Schweitzer N. J., Saks M. J.,. The CSI effect: popular fiction about forensic science affects the public's expectations about real forensic science, "Jurimetrics Journal" 2007, Vol. 47, No. 3

Shelton D. E., The "CSI Effect”: Does it Really Exist?, March 17, 2008, "National Institute of Justice Journal" 2008, Vol. 259, https://ssrn.com/abstract=1163231 (visited: November 20, 2017) 
Sullivan M. R., Armchair Detective, (in:) R. Herbert, C. Aird, J. M. Reilly, S. Oleksiw (eds.), The Oxford Companion to Crime and Mystery Writing, Oxford University Press 1999

Tomaszewski T., Girdwoyń P., Tradycja i przyszłość w nauczaniu kryminalistyki na Uniwersytecie Warszawskim, "Problemy Współczesnej Kryminalistyki” 2008, Vol. 12

Waszkiewicz P., (Inter)aktywne zajęcia na prawie? Nauczanie przedmiotów prawno-ekonomicznych, (in:) Czy wspótczesny uniwersytet potrzebuje nowoczesnej dydaktyki szkoły wyższej?, Warszawa 2011

\title{
FROM CRIMINALISTICS TO CSI: WARSAW. PRACTICAL METHODS OF TEACHING CRIMINALISTICS AT THE DEPARTMENT OF CRIMINALISTICS, UNIVERSITY OF WARSAW
}

\begin{abstract}
Summary
Forensics and criminalistics at the end of 20th century won a lot of public attention thanks to popular TV series, such as CSI: Crime Scene Investigation. It has fueled new programs in forensics worldwide. Paper presents practical approach to teaching criminalistics at the Department of Criminalistics, University of Warsaw. Brief description of differences in defining forensics and criminalistics are followed by presenting the development of hands on criminalistics class called CSI: Warsaw. Benefits and downsides of implementing such approach are discussed.
\end{abstract}

\section{KEYWORDS}

criminalistics, forensics, CSI: Warsaw, investigations

\section{SŁOWA KLUCZOWE}

kryminalistyka, nauki sądowe, CSI: Warsaw, śledztwa 